\title{
Actinomadura R39 D-Ala-D-Ala Carboxypeptidase
}

\section{Databanks}

MEROPS name:

(Actinomadura-type)

MEROPS classification: clan SE, family S13, peptidase $\mathrm{S} 13.002$

Tertiary structure: Available

Species distribution: superkingdoms Archaea, Bacteria

Reference sequence from: Actinomadura sp. R39 (UniProt: P39045)

\section{Name and History}

After the discovery of the penicillin-sensitive Streptomyces R61 D-Ala-D-Ala carboxypeptidase ([1], see Chapter 766), a similar soluble enzyme was found in the culture medium of Actinomadura R39 (formerly Streptomyces R39) [2]. Like its R61 counterpart, it catalyzed transpeptidation reactions when supplied with adequate substrates [3-6]. Inactivation by $\beta$-lactam antibiotics results from the formation of a covalent bond with the essential serine residue [7]. 


\section{Activity and Specificity}

The catalyzed reactions are:

$$
\begin{aligned}
& \text { R-D-Ala-D-Ala }+\mathrm{H}_{2} \mathrm{O} \longrightarrow \text { R-D-Ala }+ \text { D-Ala } \\
& \text { (carboxypeptidase) } \\
& \text { R-D-Ala-D-Ala }+\mathrm{R}^{\prime}-\mathrm{NH}_{2} \longrightarrow \text { R-D-Ala-NH-R' }+ \text { D-Ala } \\
& \text { (transpeptidase) }
\end{aligned}
$$

where R-D-Ala-D-Ala and $\mathrm{R}^{\prime}-\mathrm{NH}_{2}$ are the donor and acceptor substrates, respectively.

The enzyme also exhibits a so-called endopeptidase activity, i.e. it can release a $\mathrm{C}$-terminal residue bearing a large and complex side chain, which is in fact a facet of its carboxypeptidase activity.

\section{Substrate Specificity}

Good activity is observed if $\mathrm{R}=\mathrm{N}$ - $\alpha$-acetyl-L-Lys, $\mathrm{N}-\alpha$, $\mathrm{N}$ - $\varepsilon$-diacetyl-L-Lys and N- $\alpha$-acyl-meso- $\mathrm{A}_{2} \mathrm{pm}$-(L). Peptide specificity studies on the R39 enzyme have shown that the enzyme strongly interacts with a structural element consisting of the dipeptide meso- $\mathrm{A}_{2} \mathrm{pm}$ (L)-D-Ala, which is a direct mimic of the stem peptides from the Actinomadura organism ( $\mathrm{R}=\mathrm{A}_{2} \mathrm{pm}$ in the reaction described above). It seems very likely that the major substrates in vivo also contain this structural element, i.e. these substrates have a non-cross-linked $\mathrm{N}$-terminus. These could be either monomers (carboxypeptidase activity) or oligomers/polymers (endopeptidase activity) [8].

The C-terminal residue can be replaced by Gly (10\% efficiency), D-Glu (100\%) or D-Leu (75\%). Replacement of the penultimate D-Ala residue by D-Leu, Gly or L-Ala yields substrates on which the enzyme is not significantly active $[2,9]$.

The only good acceptors are glycine and D-amino acids, but the latter may have complex side chains. For instance, they may be derivatives of meso- $\mathrm{A}_{2} \mathrm{pm}$ in which the amino and carboxyl groups on the $\mathrm{D}$ center are free while those on the $\mathrm{L}$ center are engaged in peptide bonds. The best substrates closely mimic the donor and acceptor parts of the peptides in the nascent Actinomadura peptidoglycan [5]. When supplied with compounds containing both a D-Ala-D-Ala C-terminus and an adequately positioned amino group, such as the 'natural' pentapeptide L-Ala- $\gamma$-D-Glu-(L)- $\mathrm{A}_{2} \mathrm{pm}$-(L)-D-Ala-D-Ala, where $\mathrm{A}_{2} \mathrm{pm}$ is the meso isomer, the enzyme catalyzes the formation of dimers [6]. The DD-peptidase also acts as an esterase and a thioesterase on compounds of general structure R-Xaa$\mathrm{Y}-\mathrm{CH}\left(\mathrm{R}^{\prime}\right)-\mathrm{COOH}$, where $\mathrm{Y}$ is $\mathrm{O}$ or S [10] and Xaa is Gly or a $\mathrm{D}$ residue, preferentially D-Ala. These compounds are also utilized in transacylation reactions. Among these, the best reported substrate is Bz-D-Ala-S- $\mathrm{CH}_{2}-\mathrm{COOH}\left(k_{\mathrm{cat}}=\right.$ $\left.6 \mathrm{~s}^{-1}, \quad k_{\mathrm{cat}} / K_{\mathrm{m}}=330000 \mathrm{M}^{-1} \mathrm{~s}^{-1}\right)$. The structural requirements for the $\mathrm{R}$ group and stereospecificity of the thioesters are somewhat modified when compared to those for the peptides [11].

A detailed study of the reactions of 3-(D-cysteinyl) propanoyl-D-alanyl-D-alanine and 3-(D-cysteinyl) propanoyl-D-alanyl-D-thiolactate, catalyzed by the enzyme, showed DD-carboxypeptidase, DD-transpeptidase and DDendopeptidase activities. These results confirm the specificity of the enzyme for substrates exhibiting an $\mathrm{N}$-terminal $\mathrm{R}^{\prime \prime}$-CO- group whose $\mathrm{R}^{\prime \prime}$ chain contains a free D-amino acid center at the end of a rather long hydrophobic chain (for instance $\mathrm{R}^{\prime \prime}={ }^{-} \mathrm{OOC}-\mathrm{CH}\left(\mathrm{NH}_{3}{ }^{+}\right)-\mathrm{CH}_{2}-$ $\mathrm{S}-\mathrm{CH}_{2}-\mathrm{CH}_{2}-\mathrm{CO}$ ) and indicate a preference for extended D-amino acid leaving groups. It was concluded that 'a specific substrate for this enzyme, and possibly the in vivo substrate, may consist of a partly cross-linked peptidoglycan polymer where a free side chain $\mathrm{N}$-terminal un-cross-linked amino acid serves as the specific acyl group in an endopeptidase reaction' [8].

\section{Mechanism}

In the hydrolysis reaction, the enzyme follows the classical acyl enzyme pathway of serine proteases:

$$
\mathrm{E}+\mathrm{S} \leftrightarrow \mathrm{ES} \rightarrow \mathrm{ES}^{*}+\mathrm{P} 1 \rightarrow \mathrm{E}+\mathrm{P} 2
$$

where $\mathrm{ES}^{*}$ is the acyl enzyme. With the peptide $\mathrm{Ac}_{2}$-LLys-D-Ala-D-Ala, acylation is the rate-limiting step, and the acyl enzyme cannot be detected. By contrast, deacylation is strongly rate limiting with most thioesters [12].

\section{Assays and Influence of Physicochemical Conditions}

The hydrolysis of peptides is monitored by a colorimetric, discontinuous assay of the released D-alanine [13], while that of the thioesters can be followed directly at $250 \mathrm{~nm}$ [10]. Transpeptidation was formerly quantified by highvoltage paper electrophoresis [3], but HPLC techniques are now preferred [14]. The enzyme presents a broad optimum $\mathrm{pH}$ between 5.5 and 9.5. Transpeptidation is favored by high $\mathrm{pH}$, high ionic strength and high and low acceptor and donor concentrations, respectively ([5] and unpublished results of the authors).

\section{Inhibitors}

Antibiotics of the $\beta$-lactam family are very efficient transient inactivators that acylate the active-site serine according to the pathway described above for the substrates, but no P1 is formed (due to the $\beta$-lactam structure) and the deacylation step is very slow $\left(10^{-3}-10^{-6}\right.$ $\mathrm{s}^{-1}$ ), so that an inactive acyl enzyme accumulates $[15,16]$. Among the presently known enzymes, the R39 
DD-peptidase is one of the most penicillin sensitive. With some but not all $\beta$-lactams, the deacylation step does not yield the expected penicilloic acid but involves the cleavage of the C5-C6 bond of the antibiotic [17].

Boronic acids were also found to be excellent reversible inhibitors $[18,19]$. In particular, (D- $\alpha$-aminopimelylamino)-D-1-ethylboronic acid, designed to be a peptidoglycan-mimetic transition state analog inhibitor of R39, was found to be a potent inhibitor of the peptidase with a $K_{\mathrm{i}}$ value of $32 \pm 6 \mathrm{nM}$ [19]. Since it binds some 30 times more strongly than the analogous peptide substrate, the boronate may well represent a transition state analog.

\section{Structural Chemistry}

Several X-ray structures of R39 have been determined, in its apo form [20] or in complex with different inhibitors or peptides [19,21,22].

The structure of R39 is composed of three domains: a penicillin-binding domain and two domains of unknown functions (Figure 771.1). The latter two domains are inserted in the penicillin-binding domain, between the SXXK and SXN motifs, in the way of 'Matryoshka dolls'. The penicillin-binding domain shares its overall fold with other penicillin-binding proteins and the serine $\beta$-lactamases: the R39 active site is located in an extended groove between a five-stranded antiparallel $\beta$-sheet and a cluster of $\alpha$-helices. The structures with peptidoglycan mimetic peptide, cephalosporin or boronic acid have confirmed the importance of the $\mathrm{A}_{2} \mathrm{pm}$ side chain for the affinity of substrates and inhibitors with R39.

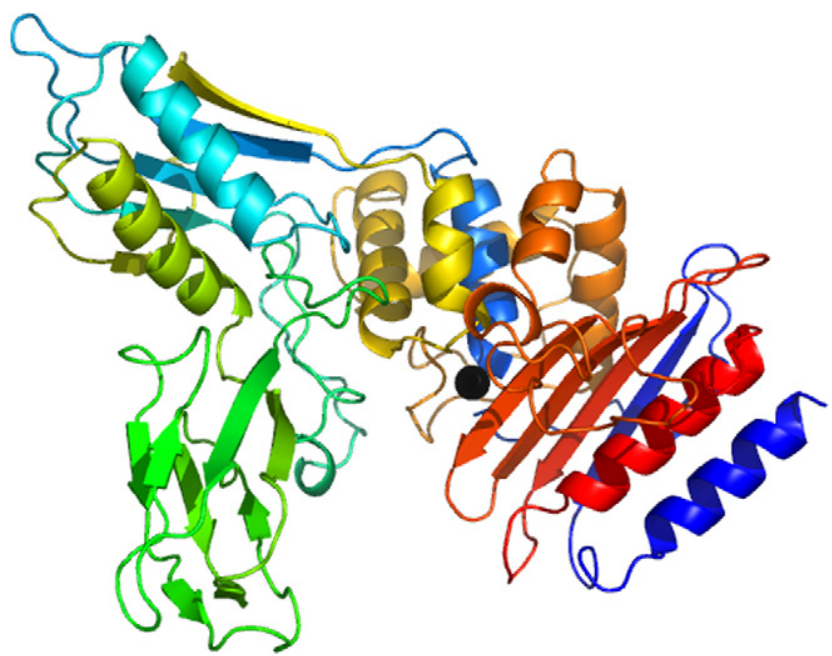

FIGURE 771.1 Structure of the R39 DD-peptidase (PDB 1W79). The active serine is shown as a black sphere.

\section{Preparation}

The enzyme was initially extracted and purified from culture filtrates of the original Actinomadura R39 strain [23]. Much higher yields were later obtained when the cloned gene was reintroduced into the R39 strain itself by electroporation of the pDML15 plasmid [24].

\section{Biological Aspects}

The physiological role of the R39 DD-peptidase is unclear. Homologous proteins have a preferential endopeptidase role in vivo but they are not essential for cell survival.

\section{Distinguishing Features}

Among the penicillin-binding proteins (PBPs), the R39 enzyme is remarkable for its high activity on simple peptides and thioesters, its ability to catalyze the formation of dimers and its high sensitivity to most $\beta$-lactams. This latter property has been utilized in the design of a sensitive method for the assay of $\beta$-lactams in biological fluids [25].

\section{Related Enzymes}

The sequence of the enzyme can be aligned with those of Bacillus subtilis PBP-4a [26] and of E. coli PBP-4 (Chapter 769) with 46 and $19 \%$ of identical residues, respectively. The X-ray structures of these proteins have confirmed their structural similarity with R39 [27,28]. Although the three proteins share some enzymatic similarities, their sensitivities to penicillins and cephalosporins can be very different. For instance, the B. subtilis PBP-4a reacts with benzylpenicillin 200-fold more slowly than the R39 enzyme. It is related to the Streptomyces R61 DD-peptidase (Chapter 766) by its high activity against -D-Ala-D-Ala terminated peptides.

\section{Further Reading}

The properties of DD-peptidases and their structural and functional relationships with $\beta$-lactamases have been considered in detail by Frère \& Joris [29], Joris et al. [30], Frère et al. [31], Ghuysen [32] and Jamin et al. [33]. Extensive details on the low molecular mass PBPs are given in a recent review [34].

\section{References}

[1] Leyh-Bouille, M., Coyette, J., Ghuysen, J.-M., Idczak, J., Perkins, H.R., Nieto, M. (1971). Penicillin-sensitive DD-carboxypeptidase from Streptomyces strain R61. Biochemistry 10, 2163-2170. 
[2] Leyh-Bouille, M., Nakel, M., Frère, J.-M., Johnson, K., Ghuysen, J.-M., Nieto, M., Perkins, H.R. (1972). Penicillin-sensitive DD-carboxypeptidases from Streptomyces strains R39 and K11. Biochemistry 11, 1290-1298.

[3] Pollock, J.J., Ghuysen, J.-M., Linder, R., Salton, M.R.J., Perkins, H.R., Nieto, M., Leyh-Bouille, M., Frère, J.-M., Johnson, K. (1972). Transpeptidase activity of Streptomyces D-alanyl-D-alanine carboxypeptidases. Proc. Natl. Acad. Sci. USA 69, 662-666.

[4] Perkins, H.R., Nieto, M., Frère, J.-M., Leyh-Bouille, M., Ghuysen, J.-M. (1973). Streptomyces DD-carboxypeptidases as transpeptidases: the specificity for amino compounds acting as carboxyl acceptors. Biochem. J. 131, 707-718.

[5] Ghuysen, J.-M., Leyh-Bouille, M., Campbell, J.N., Moreno, R., Frère, J.-M., Duez, C., Nieto, M., Perkins, H.R. (1973). Structure of the wall peptidoglycan of Streptomyces R39 and the specificity profile of its exocellular DD-carboxypeptidase-transpeptidase for peptide acceptors. Biochemistry 12, 1243-1250.

[6] Ghuysen, J.-M., Reynolds, P.E., Perkins, H.R., Frère, J.-M., Moreno, R. (1974). Effects of donor and acceptor peptides on concomitant hydrolysis and transfer reactions catalysed by the exocellular DD-carboxypeptidase-transpeptidase from Streptomyces R39. Biochemistry 13, 2539-2547.

[7] Duez, C., Joris, B., Frère, J.-M., Ghuysen, J.-M. (1981). The penicillin-binding site in the exocellular DD-carboxypeptidase-transpeptidase of Actinomadura R39. Biochem. J. 193, 83-86.

[8] Adediran, S.A., Kumar, I., Nagarajan, R., Sauvage, E., Pratt, R.F. (2011). Kinetics of reactions of the Actinomadura R39 DD-peptidase with specific substrates. Biochemistry 50, 376-387.

[9] Nieto, M., Perkins, H.R., Leyh-Bouille, M., Frère, J.-M., Ghuysen, J.-M. (1973). Peptide inhibitors of Streptomyces DD-carboxypeptidases. Biochem. J. 131, 163-171.

[10] Adam, M., Damblon, C., Plaitin, B., Christiaens, L., Frère, J.M. (1990). Chromogenic depsipeptide substrates for $\beta$-lactamases and penicillin-sensitive DD-peptidases. Biochem. J. 270, 525-529.

[11] Damblon, C., Zhao, G.-H., Jamin, M., Ledent, P., Dubus, A., Vanhove, M., Raquet, X., Christiaens, L., Frère, J.-M. (1995). Breakdown of the stereospecificity of DD-peptidases and $\beta$-lactamases with thiolester substrates. Biochem. J. 309, 431-436.

[12] Jamin, M., Adam, M., Damblon, C., Christiaens, L., Frère, J.-M. (1991). Accumulation of acyl-enzyme in DD-peptidase-catalysed reactions with analogues of peptide substrates. Biochem. J. 280, 499-506.

[13] Frère, J.-M., Leyh-Bouille, M., Ghuysen, J.-M., Nieto, M., Perkins, H.R. (1976). Exocellular DD-carboxypeptidases-transpeptidases from Streptomyces. Methods Enzymol. 45, 610-636.

[14] Jamin, M., Wilkin, J.-M., Frère, J.-M. (1993). A new kinetic mechanism for the concomitant hydrolysis and transfer reactions catalysed by bacterial DD-peptidases. Biochemistry 32, 7278-7285.

[15] Frère, J.-M., Ghuysen, J.-M., Reynolds, P.E., Moreno, R., Perkins, H.R. (1974). Binding of $\beta$-lactam antibiotics to the exocellular DD-carboxypeptidase-transpeptidase of Streptomyces R39. Biochem. J. 143, 241-249.

[16] Fuad, N., Frère, J.-M., Ghuysen, J.-M., Duez, C., Iwatsubo, M. (1976). Mode of interaction between $\beta$-lactam antibiotics and the exocellular DD-carboxypeptidase-transpeptidase from Streptomyces R39. Biochem. J. 155, 623-629.

[17] Frère, J.-M., Ghuysen, J.-M., Degelaen, J., Loffet, A., Perkins, H.R. (1975). Fragmentation of benzylpenicillin after interaction with the exocellular DD-carboxypeptidase-transpeptidases of Streptomyces R61 and R39. Nature 258, 168-170.

[18] Inglis, S.R., Zervosen, A., Woon, E.C., Gerards, T., Teller, N., Fischer, D.S., Luxen, A., Schofield, C.J. (2009). Synthesis and evaluation of 3-(dihydroxyboryl)benzoic acids as D,D-carboxypeptidase R39 inhibitors. J. Med. Chem. 52, 6097-6106.

[19] Dzhekieva, L., Rocaboy, M., Kerff, F., Charlier, P., Sauvage, E., Pratt, R.F. (2010). Crystal structure of a complex between the Actinomadura R39 DD-peptidase and a peptidoglycan-mimetic boronate inhibitor: interpretation of a transition state analogue in terms of catalytic mechanism. Biochemistry 49, 6411-6419.

[20] Sauvage, E., Herman, R., Petrella, S., Duez, C., Bouillenne, F., Frère, J.-M, Charlier, P. (2005). Crystal structure of Actinomadura R39 DD-peptidase reveals new domains in penicillin-binding proteins. J. Biol. Chem. 280, 31249-31256.

[21] Sauvage, E., Powell, A.J., Heilemann, J., Josephine, H.R., Charlier, P., Davies, C., Pratt, R.F. (2008). Crystal structures of complexes of bacterial DD-peptidases with peptidoglycan-mimetic ligands: the substrate specificity puzzle. J. Mol. Biol. 381, 383-393.

[22] Sauvage, E., Zervosen, A., Dive, G., Herman, R., Amoroso, A., Joris, B., Fonzé, E., Pratt, R.F., Luxen, A., Charlier, P., Kerff, F. (2009). Structural basis of the inhibition of class A beta-lactamases and penicillin-binding proteins by 6-beta-iodopenicillanate. J. Am. Chem. Soc. 131, 15262-15269.

[23] Frère, J.-M., Moreno, R., Ghuysen, J.-M., Perkins, H.R., Dierickx, L., Delcambe, L. (1974). Molecular weight, amino acid composition and physicochemical properties of the exocellular DD-carboxypeptidase-transpeptidase of Streptomyces R39. Biochem. J. 143, 233-240.

[24] Granier, B., Duez, C., Lepage, S., Englebert, S., Dusart, J., Dideberg, O., Van Beeumen, J., Frère, J.-M., Ghuysen, J.-M. (1992). Primary and predicted secondary structures of the Actinomadura R39 extracellular DD-peptidase, a penicillin-binding protein (PBP) related to the Escherichia coli PBP4. Biochem. J. 282, 781-788.

[25] Frère, J.-M., Klein, D., Ghuysen, J.-M. (1980). Enzymatic method for rapid and sensitive determination of beta-lactam antibiotics. Antimicrob. Agents Chemother. 18, 506-510.

[26] Duez, C., Vanhove, M., Gallet, X., Bouillenne, F., Docquier, J.D., Brans, A., Frère, J.M. (2001). Purification and characterization of PBP4a, a new low-molecular-weight penicillin-binding-protein from Bacillus subtilis. J. Bacteriol. 183, 1595-1599.

[27] Kishida, H., Unzai, S., Roper, D.I., Lloyd, A., Park, S.Y., Tame, J.R. (2006). Crystal structure of penicillin binding protein 4 (dacB) from Escherichia coli, both in the native form and covalently linked to various antibiotics. Biochemistry 45, 783-792.

[28] Sauvage, E., Duez, C., Herman, R., Kerff, F., Petrella, S., Anderson, J.W, Adediran, S.A., Pratt, R.F., Frère, J.-M, Charlier, P. (2007). Crystal structure of the Bacillus subtilis penicillin-binding protein $4 \mathrm{a}$, and its complex with a peptidoglycan mimetic peptide. J. Mol. Biol. 371, 528-539.

[29] Frère, J.-M., Joris, B. (1985). Penicillin-sensitive enzymes in peptidoglycan biosynthesis. CRC Crit. Rev. Microbiol. 11, 299-396.

[30] Joris, B., Ledent, P., Dideberg, O., Fonze, E., Lamotte-Brasseur, J., Kelly, J.A., Ghuysen, J.-M., Frère, J.-M. (1991). Comparison of the sequences of class-A beta-lactamases and of the secondary structure elements of penicillin-recognizing proteins. Antimicrob. Agents Chemother. 35, 2294-2301. 
[31] Frère, J.-M., Nguyen-Distèche, M., Coyette, J., Joris, B. (1992). Mode of action: interaction with the penicillin binding proteins, in: The Chemistry of Beta-Lactams, Page, M.I., ed., Glasgow: Chapman \& Hall, pp. 148-197.

[32] Ghuysen, J.-M. (1991). Serine $\beta$-lactamases and penicillin-binding proteins. Annu. Rev. Microbiol. 45, 37-67.
[33] Jamin, M., Wilkin, J.-M., Frère, J.-M. (1995). Bacterial DD-transpeptidases and penicillin. Essays Biochem. 29, 1-24.

[34] Sauvage, E., Kerff, F., Terrak, M., Ayala, J.A., Charlier, P. (2008). The penicillin-binding proteins: structure and role in peptidoglycan biosynthesis. FEMS Microbiol. Rev. 32, 234-258.

\section{Eric Sauvage}

Centre for Protein Engineering (CIP), Universite de Liege, Institut de Physique B5, Sart Tilman, B 4000 Liege 1, Belgium. Email: eric.sauvage@ulg.ac.be

\section{Jean-Marie Frère}

Centre for Protein Engineering, Institut de Chimie (B6) and Institut de Physique (B5), Université de Liège, Sart Tilman, B 4000 Liège, Belgium.

Email: jmfrere@ulg.ac.be

Handbook of Proteolytic Enzymes, 3rd Edn ISBN: 978-0-12-382219-2
(C) 2013 Elsevier Ltd. All rights reserved. DOI: http://dx.doi.org/10.1016/B978-0-12-382219-2.00771-7 